DOI: 10.20472/IAC.2020.053.021

\title{
FERNANDO ZANELLA
}

United Arab Emirates University, United Arab Emirates

\section{PETER OYELERE}

United Arab Emirates University, United Arab Emirates

\section{ARE NON-STICKY COSTS ENDEMIC IN THE ARABIAN GULF REGION? EVIDENCE FROM PUBLICLY LISTED COMPANIES}

\begin{abstract}
:
We investigate the endemism of non-sticky costs in resources-rich emerging economies of Arabian Gulf Co-operation Council (GCC) countries. Evidence already exists for non-sticky costs amongst publicly-listed companies in the United Arab Emirates (UAE). This study extends the investigation of the phenomenon to four other member countries of the GCC - Saudi Arabia, Qatar, Kuwait, and Bahrain. We measured the degree of adjustment between operating revenues and costs for publicly listed companies in all GCC countries. We did not find evidence of sticky costs in four of the five countries suggesting that the endemic absence or curtailment of the main benefits of western-style employment protection legislation (EPL) available in other national jurisdictions is a possible explanation for why variable costs, such as labor costs, adjust easier to changes in sales thus eliminating the main cause of cost stickiness. This result, which may be generalizable to other similar emerging economies, raises some practical questions that may need to be addressed by relevant authorities in the respective countries of the region.
\end{abstract}

\section{Keywords:}

Sticky costs, Employment Protection Legislation, GCC countries, Expatriates

JEL Classification: M20, M41 